\title{
'Candidatus Helicobacter suis', a gastric helicobacter from pigs, and its phylogenetic relatedness to other gastrospirilla
}

\author{
Dominic De Groote, ${ }^{1}$ Leen-Jan van Doorn, ${ }^{2}$ Richard Ducatelle, ${ }^{1}$ \\ Anita Verschuuren, ${ }^{2}$ Freddy Haesebrouck, ${ }^{1}$ Wim G. V. Quint, ${ }^{2}$ \\ Katri Jalava ${ }^{3}$ and Peter Vandamme ${ }^{4}$
}

1 Department of Pathology, Bacteriology and Avian Diseases, Faculty of Veterinary Medicine University of Ghent, Salisburylaan 133, B-9820 Merelbeke, Belgium

2 Delft Diagnostic Laboratory, R. de Graafweg 7, $2600 \mathrm{GA}$, Delft, The Netherlands

3 Department of Food and Environmental Hygiene, Faculty of Veterinary Medicine, University of Helsinki, PO Box 57, 00014 Helsinki, Finland

4 Department of Microbiology, Faculty of Sciences, University of Ghent, Ledeganckstraat, B-9000 Ghent, Belgium

\author{
Author for correspondence: Dominic De Groote. Tel: + 3292647745 . Fax; + 3292647789 \\ e-mail: dominic.degroote@ rug.ac.be
}

\begin{abstract}
'Gastrospirillum suis' is an uncultured, tightly spiral micro-organism that has been associated with ulcer disease in the stomachs of pigs. It was the purpose of this study to determine the phylogenetic position of ' $G$. suis'. Stomachs of five slaughterhouse pigs, originating from different Belgian and Dutch farms, were selected on the basis of the presence of ' $G$. suis'-like bacteria, as demonstrated by biochemical, immunohistochemical and electron microscopical data. Bacterial 16S rDNA was amplified by PCR using broadrange primers and five helicobacter-like sequences were determined either by direct or indirect sequence analysis. An inter-sequence homology of $99.7 \%$ was observed, suggesting that the sequences originated from strains belonging to a single species. Phylogenetic analysis of the consensus sequence placed the organism within the genus Helicobacter, where it formed a distinct sub-group together with other gastrospirillum-like bacteria (Helicobacter felis, Helicobacter bizzozeronii, Helicobacter salomonis and 'Helicobacter heilmannii' types 1 and 2). Diagnostic PCR primers and a probe were developed that differentiated the porcine sequences from all known helicobacters. These results indicate that the porcine sequences represent a single taxon within the genus Helicobacter. The low similarity level towards $H$. salomonis $(96.6 \%)$, its closest validly named neighbour, strongly suggests that this taxon is a novel Helicobacter species. In situ hybridization experiments linked the reference sequence to the ' $G$. suis'-like bacteria. On the basis of these results, we propose the name 'Candidatus Helicobacter suis' for this gastric helicobacter from pigs.
\end{abstract}

Keywords: Helicobacter, 'Gastrospirillum suis', pig, stomach, PCR

\section{INTRODUCTION}

At the end of the 19th century, spiral organisms were described for the first time in the stomachs of animals by Rappin (1881) and Bizzozero (1893). It was not until 1984, after the isolation of Helicobacter pylori from the human stomach (Marshall \& Warren, 1984) and its association with chronic gastritis, peptic ulcer disease and gastric cancer (Cover \& Blaser, 1995; Blaser et al., 1991; Parsonnet et al., 1991), that

The GenBank accession number for the 165 rDNA nucleotide reference sequence of 'Candidatus Helicobacter suis' V2BXA is AF127028. scientific interest in these organisms emerged. Over the years, other Helicobacter species have been isolated from many different animals. To date, the genus Helicobacter consists of 18 validly named species $(\mathrm{On}$, 1996; Franklin et al., 1996; Mendes et al., 1996b; Jalava et al., 1997; Shen et al., 1997) and constitutes, together with the genera Wolinella, Campylobacter and Arcobacter, the $\varepsilon$-subdivision of the Proteobacteria, also known as rRNA superfamily VI (Vandamme et al., 1991).

Within the genus Helicobacter, a phylogenetic subgroup of morphologically similar bacteria can be distinguished. These bacteria, characterized by their 
long and tightly coiled (gastrospirillum-like) appearance, have been observed in gastric biopsies of humans, cats, lemurs, dogs, pigs and exotic carnivores (Dent et al., 1987; Lee et al., 1988; O'Rourke et al., 1992; Hänninen et al., 1996; Jalava et al., 1997; Queiroz et al., 1990; Eaton et al., 1993; Jakob et al., 1997). Three species with this morphology (Helicobacter felis, Helicobacter bizzozeronii, Helicobacter salomonis) have been cultured and characterized from gastric samples of cats and dogs (Paster et al., 1991; Hänninen et al., 1996; Jalava et al., 1997).

In pigs, gastrospirillum-like bacteria were observed in the antral pits and at the mucosal surface of the stomach (Queiroz et al., 1990) and have provisionally been named 'Gastrospirillum suis' (Mendes et al., 1990). Histopathological studies associated this bacterium with pyloric lymphonodular gastritis (Mendes et al., 1991) and gastric ulcer disease of the pars oesophagea in pigs (Barbosa et al., 1995; Queiroz et al., 1996). Although cultivation of ' $G$. suis' in vitro has been unsuccessful (Queiroz et al., 1990; unpublished data), cultivation in vivo in mice and rats has been reported (Moura et al., 1993; Mendes et al., 1996a). Several helicobacter-like bacteria have been cultured from the stomach of swine, but none had the characteristic gastrospirillum morphology (Seymour et al., 1994; Dewhirst et al., 1994; On et al., 1995).

As ' $G$. suis' remains unculturable, an official species designation is impossible according to the guidelines of the International Code of Nomenclature of Bacteria (Lapage et al., 1992), which states the necessity of a broad range of phenotypic and phylogenetic data. Murray \& Schleifer (1994) anticipated this problem and proposed a provisional status to record the properties of putative taxa of prokaryotes. This proposal was implemented in 1995 by the International Committee on Systematic Bacteriology, by the introduction of the provisional status Candidatus for the description of uncultivable organisms based upon genomic data and to a certain extent on structural, metabolic, reproductive and environmental characteristics (Murray \& Stackebrandt, 1995).

It was the object of this study to determine the taxonomic position of the porcine gastrospirillum-like bacteria according to the guidelines of Murray \& Schleifer (1994). In the present study, we propose a new candidate species, 'Candidatus Helicobacter suis', a gastric Helicobacter species from pigs.

\section{METHODS}

Samples. Stomachs from five healthy slaughterhouse pigs were selected, all originating from different farms in Belgium and the Netherlands. The stomachs were opened longitudinally along the greater curvatura and rinsed gently with tap water. A small mucosal fragment was taken from each stomach near the torus pyloricus and placed into an urease test tube (CUTest; Temmler Pharma) for $2 \mathrm{~h}$ at $37^{\circ} \mathrm{C}$. Mucosal biopsies from the antral part of the stomach were taken along the curvatura major $(n=2)$ and the curvatura minor $(n=2)$ for immunohistochemical evaluation and placed into $4 \%$ buffered formalin. For electron microscopy, samples were taken from the same places and fixed in $0.1 \mathrm{M}$ cacodylate buffer $(\mathrm{pH} 7.0)$ containing $5 \%$ glutaraldehyde and $0.15 \%(\mathrm{w} / \mathrm{v})$ ruthenium red. A mucosal fragment of each stomach was also taken for PCR, placed into sterile PBS and frozen in liquid nitrogen. Special care was taken during sampling to avoid cross-contamination.

Reference strains. Fifteen Helicobacter strains were used to test the specificity of the 'Candidatus Helicobacter suis'specific PCR assay (Table 1). Strains were grown on $5 \%$ Mueller-Hinton blood agar and incubated at $37^{\circ} \mathrm{C}$ in a microaerobic atmosphere containing approximately $5 \% \mathrm{O}_{2}$, $3.5 \% \mathrm{CO}_{2}, 7.5 \% \mathrm{H}_{2}$ and $84 \% \mathrm{~N}_{2}$. Bacteriological purity was checked by plating and Gram-staining.

Immunohistochemistry. An immunohistochemical staining procedure was performed on the formalin-fixed, paraffinembedded pyloric samples of each animal, to look for the presence of gastrospirillum-like organisms. Sections $(4 \mu \mathrm{m}$ thick) of formalin-fixed, paraffin-embedded tissues were placed on 3-aminopropyl triethoxysilane (APES)-coated slides (Sigma) and dried overnight at $60^{\circ} \mathrm{C}$. After dewaxing with xylene and rehydration in series with ethanol and distilled water, sections were placed in citrate buffer $(0 \cdot 1 \mathrm{M}$ with $2 \%$ urea) and boiled (one period of $3 \mathrm{~min}$, two periods of $5 \mathrm{~min}$ ) in an $800 \mathrm{~W}$ microwave oven (Whirlpool M611) to elicit antigen retrieval. Slides were then incubated with $12 \%$ $\mathrm{H}_{2} \mathrm{O}_{2}$ in methanol (30 min) in order to block endogenous peroxidase activity and were subsequently pre-incubated with $30 \%$ normal goat serum in PBS for 30 min to reduce non-specific antibody binding. The sections were incubated overnight at $21^{\circ} \mathrm{C}$ in a moist chamber with a mouse polyclonal antibody directed against $H$. pylori (DAKO), diluted $1: 20$ in PBS. The sections were washed and incubated with biotinylated swine anti-rabbit immunoglobulin $\left(21^{\circ} \mathrm{C}\right.$, $30 \mathrm{~min}$ ) and, after rinsing, were covered with peroxidaseconjugated streptavidin-biotin complex (ABC). Peroxidase activity was developed using $\mathrm{H}_{2} \mathrm{O}_{2}$ with diaminobenzidine (DAB) as a chromogen (Fast DAB Tablet Set; Sigma). Finally, the sections were counter-stained with Mayer's haematoxylin and mounted. The H. pylori-specific polyclonal antibodies were replaced by foetal calf serum in Tris/ $\mathrm{HCl}$ buffer $(\mathrm{pH} \mathrm{7.6)}$ for negative controls. A section of a mouse stomach experimentally infected with $H$. pylori LMG $7539^{\mathrm{T}}$ was taken as a positive control.

Transmission electron microscopy. Two different antral biopsies were selected for electron microscopic evaluation on the basis of the high numbers of gastrospirillum-like organisms in the corresponding immunostained slides. After dehydration in a graded series of acetone washes, the samples were embedded in Spurr low-viscosity resin. Ultrathin sections were post-stained with uranyl acetate and lead citrate and examined with an electron microscope (Phillips $201 \mathrm{TEM}$ ) at an accelerating voltage of $60 \mathrm{kV}$.

DNA extraction. DNA was isolated from the scrapings of the gastric biopsies and from the reference strains by lysis with guanidinium isothiocyanate and bound to silica particles (Boom et al., 1990).

Primers and PCR amplification of 165 rDNA. Broad-range PCR primers $H 33 f$, H6If and $H 1368 r$ were selected from rRNA superfamily VI-specific regions of the 16S rRNA gene by aligning multiple 16S rDNA sequences from Helicobacter, Campylobacter, Arcobacter and Wolinella species. The use of broad-range primer $1492 R P L$ was suggested by 
Table 1. Helicobacter strains used for the evaluation of the 'Candidatus Helicobacter suis'-specific PCR

\begin{tabular}{|c|c|c|}
\hline Taxon & Source & Strain \\
\hline H. acinonychis & Cheetah gastric mucosa & LMG $12684^{\mathrm{T}}$ \\
\hline H. cinaedi & Human faeces & LMG $7543^{\mathrm{T}}$ \\
\hline Helicobacter sp. CLO-3 & Human rectal swab & LMG 7792 \\
\hline H. fennelliae & Human faeces & LMG 11759 \\
\hline H. pametensis & Tern faeces & LMG $12678^{\mathrm{T}}$ \\
\hline Helicobacter sp. Bird B & Bird faeces & LMG 12679 \\
\hline Helicobacter sp. Bird C & Bird faeces & LMG 13642 \\
\hline H. hepaticus & Mouse liver & LMG $16316^{\mathrm{T}}$ \\
\hline H. pullorum & Broiler chicken mucosa & LMG 16318 \\
\hline H. mustelae & Ferret gastric mucosa & LMG $18044^{\mathrm{T}}$ \\
\hline H. canis & Dog faeces & LMG $18086^{\mathrm{T}}$ \\
\hline H. muridarum & Mouse intestinal mucosa & LMG $14378^{\mathrm{T}}$ \\
\hline H. bizzozeronii & Dog gastric mucosa & $12 \mathrm{~A}$ \\
\hline H. salomonis & Dog gastric mucosa & CCUG $37845^{\mathrm{T}}$ \\
\hline H. felis & Cat gastric mucosa & CCUG $28539^{\mathrm{T}}$ \\
\hline
\end{tabular}

Table 2. Oligonucleotide primers and probe used for PCR amplification, sequencing of genes encoding $16 \mathrm{~S}$ rRNA and Southern blot hybridization

Primer locations are given relative to the sequence of the E. coli $16 \mathrm{~S}$ rRNA gene.

\begin{tabular}{|c|c|c|}
\hline Primer & Sequence $\left(5^{\prime}-3^{\prime}\right)$ & Location \\
\hline$H 33 f$ & ACGCTGGCGGCGTGCCTAATACATGCAAGTCG & $33-64$ \\
\hline$H 1368 r$ & GGTGAGTACAAGACCCGGGAACGTATTCACCG & $1368-1388$ \\
\hline H6lf & TGCAAGTCGAACGATGAAGC & $61-76$ \\
\hline$H 274 f$ & AGGCTATGACGGGTATCCGGCCTGAGA & $274-299$ \\
\hline $1492 R P L$ & GCCGCCCGGGTTACCTTGTTACGACTT & $1491-1517$ \\
\hline H390f & GCAGCAACGCCGCGTGGAGGATGA & $390-413$ \\
\hline$H 1053 r$ & ACGAGCTGACGACAGCCGTG & $1053-1072$ \\
\hline$V 832 f$ & TTGGGAGGCTTTGTCTTTCCA & $832-852$ \\
\hline$V 1000 f$ & AGGAATTCCCTAGAAATAGGG & $1000-1020$ \\
\hline$V 1261 r$ & GATTAGCTCTGCCTCGCGGCT & $1261-1281$ \\
\hline
\end{tabular}

Weisburg et al. (1991). A genus Helicobacter-specific primer $H 274 f$ was adapted from primer $274 r$ described by Dewhirst et al. (1994) (Table 2). Primer combinations $H 33 f-H 1368 r$, $H 274 f-1492 R P L$ and $H 61 f-1492 R P L$ were used to amplify $\sim 1.3, \sim 1.2$ and $\sim 1.4 \mathrm{kbp}$ fragments, respectively. PCR was performed in a volume of $50 \mu \mathrm{l}$ containing $10 \mathrm{mM}$ Tris/ $\mathrm{HCl}(\mathrm{pH} 8 \cdot 3), 50 \mathrm{mM} \mathrm{KCl}, 3.5 \mathrm{mM} \mathrm{MgCl}_{2} 200 \mu \mathrm{M}$ of each dNTP, 1.5 U AmpliTaq Gold (Perkin-Elmer) and $25 \mathrm{pmol}$ of both forward and reverse primers (Eurogentec). Reaction mixtures were covered with mineral oil and PCR was performed in a Biomed-60 thermocycler under the following conditions: $9 \mathrm{~min}$ pre-incubation at $94{ }^{\circ} \mathrm{C}$ to activate AmpliTaq Gold, followed by 50 cycles of $30 \mathrm{~s}$ at $94^{\circ} \mathrm{C}, 45 \mathrm{~s}$ at $55^{\circ} \mathrm{C}$ and $45 \mathrm{~s}$ at $72^{\circ} \mathrm{C}$. Final extension was performed for $5 \mathrm{~min}$ at $72^{\circ} \mathrm{C}$.

Analysis of PCR products. PCR products were separated on $1 \%$ agarose gels and stained with ethidium bromide. DNA extractions of Helicobacter acinonychis LMG 12684
(Trüper \& De'Clari, 1997) and Helicobacter mustelae LMG 8776 were used as positive controls. In order to determine whether PCR products were derived from helicobacter-like organisms, the desired DNA bands were cut from the gels, diluted $1: 1$ in distilled water and sequenced using $5^{\prime}$ indocarbocyanin (Cy5)-labelled H61f and 1492RPL primers. Partial sequences were screened for homologous sequences using the NCBI GENINFO BLAST network service (http://www.ncbi.nlm.nih.gov/BLAST/) (Altschul et al., 1997).

DNA cloning and sequencing. PCR products comprising the $16 \mathrm{~S}$ rDNA sequences from two different stomach samples (V2B, V4A) were cloned into plasmid vector pGEM-T (Promega Biotech) according to the manufacturer's instructions and transformed into Escherichia coli JM109 using standard procedures. Plasmids were purified using the Easy Prep Plasmid Prep kit (Pharmacia Biotech). Sequences were determined by the T7 sequencing system (Pharmacia 
Table 3. Strains used for phylogenetic analysis

\begin{tabular}{|c|c|c|c|}
\hline Taxon & Source & Accession no. & Strain/clone \\
\hline 'H. heilmannii' type 1 & Human gastric mucosa & L10079 & Clone G1Al \\
\hline 'H. heilmannii' type 2 & Human gastric mucosa & L10080 & Clone G2A9 \\
\hline H. acinonychis & Cheetah gastric mucosa & M88148 & Eaton $90-119-3$ \\
\hline H. bilis & Mouse liver & U18766 & MIT 93-1909 \\
\hline H. bizzozeronii & Dog gastric mucosa & Y09404 & CCUG 35045 \\
\hline H. canis & Dog faeces & L13464 & NCTC 12739 \\
\hline H. cholecystus & Mouse liver & U46129 & $\mathrm{Hkb}-1$ \\
\hline H. cinaedi & Human faeces & M88150 & CCUG 18818 \\
\hline H. felis & Cat gastric mucosa & M57398 & CS1 \\
\hline H. fennelliae & Human faeces & M88154 & CCUG 18820 \\
\hline H. hepaticus & Mouse liver & U07574 & FRED1 \\
\hline H. muridarum & Mouse intestinal mucosa & M80205 & ST1 \\
\hline H. mustelae & Ferret gastric mucosa & M35048 & ATCC 43772 \\
\hline H. nemestrinae & Macaque gastric mucosa & $\mathrm{X} 67854$ & ATCC $49396^{\mathrm{T}}$ \\
\hline H. pametensis & Swine faeces & M88155 & M17 Seymour \\
\hline H. pullorum & Broiler chicken caecum & L36141 & NCTC 12824 \\
\hline H. pylori & Human gastric mucosa & M88157 & ATCC 43504 \\
\hline H. salomonis & Dog gastric mucosa & Y09405 & CCUG $37845^{\mathrm{T}}$ \\
\hline H. trogontum & Rat colon mucosa & U65103 & LRB 8581 \\
\hline H. rodentium & Mouse intestinal mucosa & U96297 & MIT 96-1312 \\
\hline Arcobacter butzleri & Human & L14626 & CCUG 10373 \\
\hline Campylobacter jejuni & Human faeces & L14630 & CCUG 24567 \\
\hline Wolinella succinogenes & Cattle abomasal mucosa & M88159 & ATCC 29543 \\
\hline
\end{tabular}

Biotech). Two primers flanking the multiple cloning sites ( $T 7$ and SP6) as well as internal primers H390f and H1053r (Table 2) were used. Sequence analysis was performed with the PCGENE software (IntelliGenetics).

PCR amplicons of three other gastric samples (V5, V14, V19) were sequenced without prior cloning (referred to below as direct sequence analysis).

Phylogenetic analysis. Phylogenetic analysis was performed using the GENCOMPAR 2.0 software package (Applied Maths). All five 'Candidatus Helicobacter suis' sequences and the sequences of strains belonging to the same phylogenetic lineage (Table 3) were aligned. A phylogenetic tree and corresponding similarity matrix were constructed using the neighbour-joining method. Unknown bases and gaps were not considered in the numerical analysis.

Diagnostic PCR assay and Southern blot hybridization. 'Candidatus Helicobacter suis'-specific primers (V832f and $V 1261 r$ ) were selected from variable rDNA regions of the sequences determined by direct and indirect sequence analysis, comprising a $\sim 0.4 \mathrm{kbp} 16 \mathrm{~S}$ rDNA fragment. Within this fragment, a 'Candidatus Helicobacter suis'-specific probe, V1000f (Table 2), was selected for hybridization purposes. PCR was performed in a volume of $50 \mu 1$ containing $10 \mathrm{mM}$ Tris $/ \mathrm{HCl}(\mathrm{pH} 8.3), 50 \mathrm{mM} \mathrm{KCl}, 2.5 \mathrm{mM}$ $\mathrm{MgCl}_{2}, 200 \mu \mathrm{M}$ of each dNTP, $1.5 \mathrm{U}$ AmpliTaq Gold and 25 pmol of both forward and reverse primers. PCR amplification was performed under the following conditions: 9 min pre-incubation at $94{ }^{\circ} \mathrm{C}$ to activate AmpliTaq Gold, followed by 40 cycles of $30 \mathrm{~s}$ at $94^{\circ} \mathrm{C}, 45 \mathrm{~s}$ at $60^{\circ} \mathrm{C}$ and $90 \mathrm{~s}$ at $72^{\circ} \mathrm{C}$. Final extension was performed for $5 \mathrm{~min}$ at $72{ }^{\circ} \mathrm{C}$. Plasmid DNA from the cloned 16S rDNA fragments (V2B, $\mathrm{V} 4 \mathrm{~A}$ ) was used as a positive control. DNA extracted from the stomach of a gnotobiotic piglet was used as a negative control.

To test the specificity of the primers, PCR was also performed on DNA extracts of 15 different Helicobacter species (Table 1), including all of the closest phylogenetic neighbours of 'Candidatus Helicobacter suis' and a random selection of other helicobacters.

PCR products were separated on $2 \%$ agarose gels, stained with ethidium bromide and transferred to Hybond-N+ (Amersham) by electro-blotting. Southern blot hybridization was performed with the $\left[\gamma^{32} \mathrm{P}\right] \mathrm{ATP}$-labelled probe $V 1000 f$ according to standard procedures (Amersham Pharmacia Biotech). In order to ensure the specificity of the probe hybridization, blots were washed twice with $0 \cdot 1 \times$ SSC, $0 \cdot 1 \%$ SDS at $55^{\circ} \mathrm{C}$.

In situ hybridization. To link the derived sequence to the corresponding organism, an in situ hybridization procedure was performed on the formalin-fixed, paraffin-embedded pyloric samples from each animal. $\mathrm{A} \sim 0.4 \mathrm{~kb}$ digoxigeninlabelled probe was synthesized using the PCR Dig Probe Synthesis kit (Boehringer Mannheim) in combination with the 'Candidatus Helicobacter suis'-specific primers $V 832 f$ and $V 1261 r$ (Table 2). PCR conditions were identical to those described in the diagnostic PCR assay. The resulting PCR product was purified using the High Pure PCR Product Purification kit (Boehringer Mannheim) following the manufacturer's instructions.

Sections $(4 \mu \mathrm{m})$ of the paraffin-embedded tissues were mounted on APES-coated slides (Sigma) and fixed by heating for $1 \mathrm{~h}$ at $60^{\circ} \mathrm{C}$. The sections were deparaffinized in xylene $(2 \times 5 \mathrm{~min})$, rehydrated through a graded ethanol 
series and washed twice in PBS for 5 min each. Sections were then treated with proteinase $\mathrm{K}$ (DAKO) for $15 \mathrm{~min}$ at $37^{\circ} \mathrm{C}$ in a humidified chamber. The enzyme was inactivated by treatment with $0.2 \%$ glycine in PBS for 3 min. Sections were washed twice in PBS for 5 min each, dehydrated in graded ethanol series and air-dried. Tissues were circumscribed with a DAKO Pen (DAKO) to avoid liquid spillage during further processing. For the hybridization step, sections were covered with 5-15 $\mu$ l hybridization solution consisting of 5 ng labelled probe $\mu^{-1}$ in $50 \%$ deionized formamide, $2 \times$ SSC, $10 \%$ dextran sulfate, $0 \cdot 25 \mu$ g yeast tRNA $\mu 1^{-1}, 0 \cdot 5 \mu \mathrm{g}$ heat-denatured salmon sperm DNA $\mu 1^{-1}$ and $1 \times$ Denhardt's solution. Sections were covered with a coverslip. To denature the probe, sections were heated for $10 \mathrm{~min}$ at $95^{\circ} \mathrm{C}$ and chilled on ice for $10 \mathrm{~min}$. Slides were then incubated overnight at $37^{\circ} \mathrm{C}$ in a humidified chamber. To remove the unbound probe, the coverslips were removed and the sections were washed in $2 \times$ SSC and $1 \times$ SSC at room temperature for $10 \mathrm{~min}$ each followed by washes in $0 \cdot 3 \times$ $\mathrm{SSC}$ at $40^{\circ} \mathrm{C}$ for $10 \mathrm{~min}$ and at room temperature for $10 \mathrm{~min}$.

All steps involving the immunological detection of the hybridized probe were performed at room temperature. The sections were treated first for $30 \mathrm{~min}$ in buffer $1(100 \mathrm{mM}$ Tris $/ \mathrm{HCl}, 150 \mathrm{mM} \mathrm{NaCl}, \mathrm{pH} 7.5)$ containing $2 \%$ normal goat serum and $0.3 \%$ Triton X-100, followed by a $3 \mathrm{~h}$ incubation with diluted (1:30 in buffer 1) anti-digoxigenin antibodies conjugated to horseradish peroxidase (DAKO). Unbound antibodies were removed by washing gently on a shaker, first with buffer 1 and then with buffer $2(100 \mathrm{mM}$ Tris/ $\mathrm{HCl}, 100 \mathrm{mM} \mathrm{NaCl}, 50 \mathrm{mM} \mathrm{MgCl}, \mathrm{pH} 9 \cdot 5$ ) for $15 \mathrm{~min}$ each. To optimize the level of detection, the Tyramid Signal Amplification system (NEN Life Science Products) was applied on each section, following the manufacturer's instructions. The hybridized probe was then visualized using $\mathrm{H}_{2} \mathrm{O}_{2}$ with DAB as the chromogen. Finally, the sections were counter-stained with Mayer's haematoxylin and mounted.

Nucleotide sequence accession numbers. Accession numbers of the 16S rDNA gene sequences used for the phylogenetic analysis are listed in Table 3 .

\section{RESULTS}

\section{Urease activity and immunohistochemical evaluation}

Tightly coiled, immunostained spiral organisms, morphologically similar to 'G. suis' (Queiroz et al., 1990), were observed in all stomach samples $(5 / 5)$, which was consistent with the presence of urease activity $(5 / 5)$. The gastrospirillum-like organisms were seen lying separately or in small clusters with a patchy distribution over the sample and were found mostly in the superficial part of the gastric crypts. Some bacteria revealed bipolar immunostained flagella (Fig. 1). Immunostained coccoid-like organisms were also observed in the pyloric crypts. Only $H$. pylori-like bacteria were stained in the positive control, while no labelling was observed in the negative controls.

\section{Transmission electron microscopy}

Longitudinal and transversal sections of spiral organisms could be seen within the gastric crypts of the

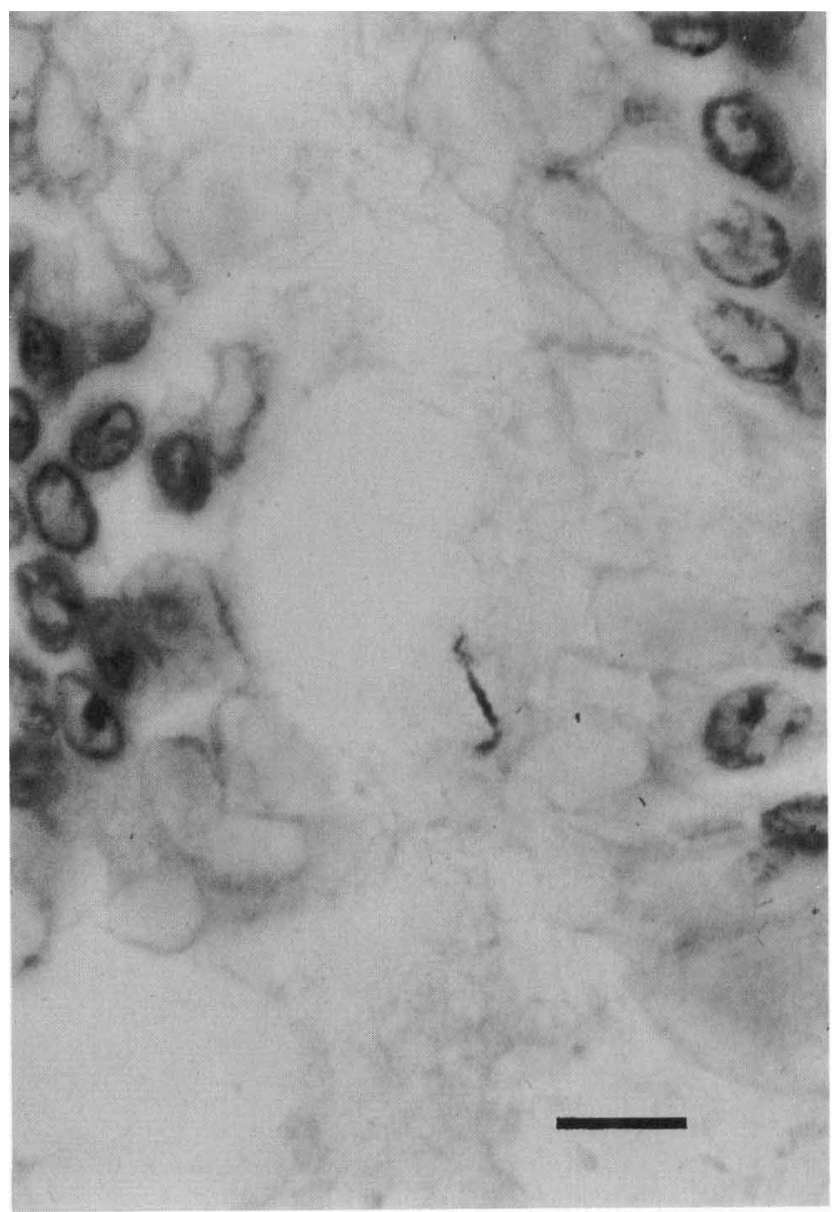

Fig. 1. Immunohistochemical staining of a gastrospirillum-like organism in the gastric crypts of a pig showing a spiral morphology and bipolar multiple flagella. Bar, $10 \mu \mathrm{m}$.

antral region. All bacteria had the same characteristic, tightly coiled appearance, typical of helicobacters with the gastrospirillum morphology (Fig. 2). The length of cells varied from 2.5 to $3.5 \mu \mathrm{m}$ and they were approximately $0.6 \mu \mathrm{m}$ wide. Multiple complete spiral turns with a wavelength of $\sim 600 \mathrm{~nm}$ were seen in all longitudinal sections. Polarly flagellated cells were observed, the number of flagella ranging from one to five. The presence of a flagellar sheath was unclear. The bacteria were not seen within cells, nor was there any obvious association with the surrounding epithelial cells.

\section{Amplification, cloning and sequencing of helicobacter-like 165 rDNA fragments}

Several combinations of PCR primers yielded sequences of the expected size. The length of these amplified fragments varied between 1.2 ( $H 274 f-$ $1492 R P L)$ and $1.4 \mathrm{kbp}(H 61 f-1492 R P L)$. The latter primer combination was used to examine all samples. The $16 \mathrm{~S}$ rDNA sequences of two different clones were 


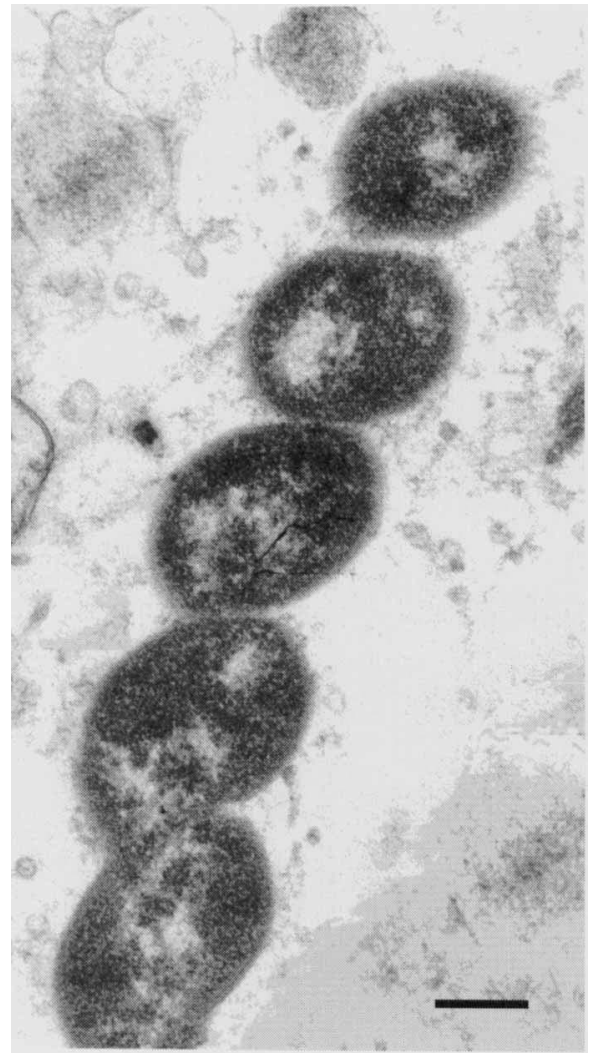

Fig. 2. Transmission electron micrograph showing a crosssection of a ' $G$. suis'-like bacterium in the crypts of the antral part of the stomach of a pig. Bar, $300 \mathrm{~nm}$.

determined (V2BXA, V4AXA). Additional sequences of three other samples (V5, V14, V19) were determined by direct sequence analysis.

\section{Sequences and phylogenetic analysis}

The five sequences that were determined varied in length from 1345 to $1421 \mathrm{bp}$. Pairwise comparisons between $1345 \mathrm{bp}$ consensus fragments of these sequences revealed a minimum similarity of $97.7 \%$. One reference sequence of $1421 \mathrm{bp}$, obtained from PCR product V2BXA, was used for phylogenetic analysis. A similarity matrix was calculated based on comparisons of $16 \mathrm{~S}$ rDNA sequences of all Helicobacter species, 'Helicobacter heilmannii' types 1 and 2, Campylobacter jejuni, Arcobacter butzleri and Wolinella succinogenes (Table 3 ). The sequence of the porcine gastrospirillum-like organism formed a distinct sub-group in this analysis within the Helicobacter lineage, together with other gastrospirilla: $H$. felis, $H$. bizzozeronii, $H$. salomonis and ' $H$. heilmannii' types 1 and 2 . The sequence was highly similar to that of ' $H$. heilmannii' type 1 ( $99 \cdot 5 \%$ similarity). The similarity to other gastrospirillum-like bacteria, H. felis, H. bizzozeronii, $H$. salomonis and ' $H$. heilmannii' type 2 , was clearly lower: $96 \cdot 4,96 \cdot 5,96 \cdot 6$ and $96 \cdot 8 \%$, respectively.

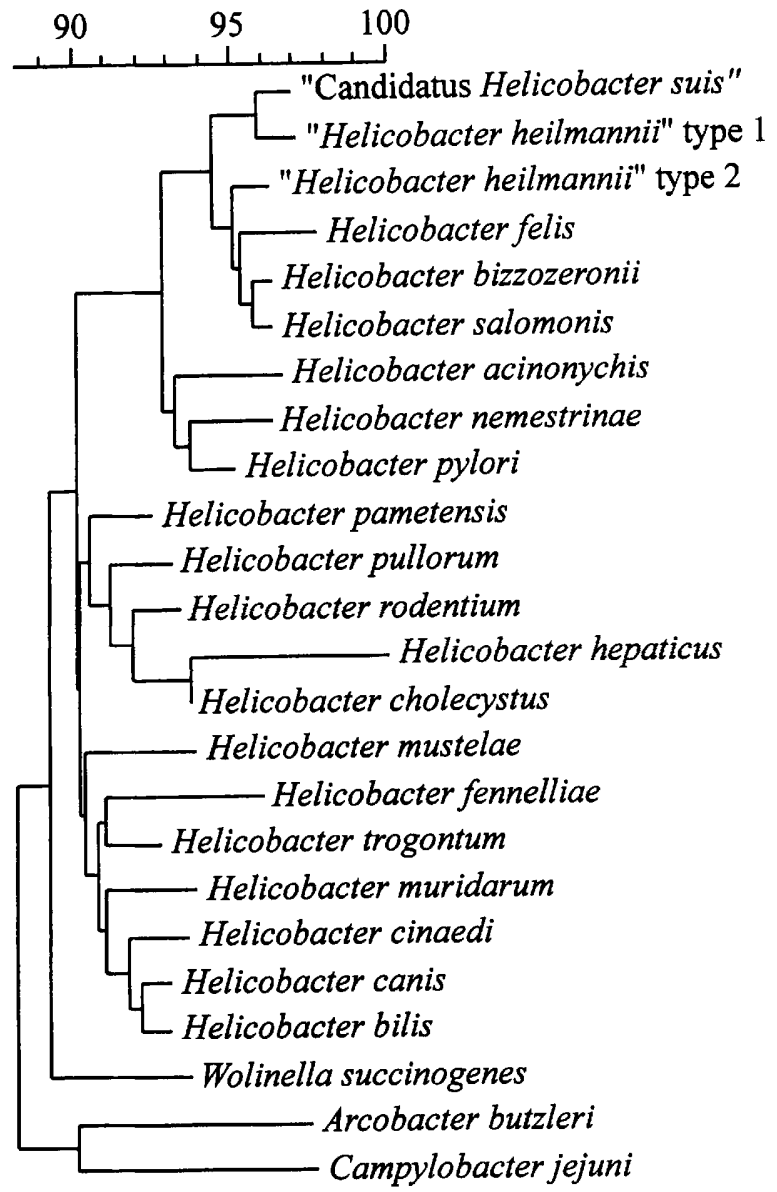

Fig. 3. Phylogenetic tree for 23 strains of Helicobacter, Campylobacter, Arcobacter and Wolinella species on the basis of 165 rDNA sequence similarity. Divergence of nucleotide sequences, as determined by measuring the length of horizontal lines connecting any two species, is shown as a percentage.

The reference sequence was clearly distinct from sequences belonging to other genera from superfamily VI, as shown by $86 \cdot 2,84.7$ and $89.6 \%$ similarity with $C$. jejuni, $A$. butzleri and $W$. succinogenes, respectively. A phylogenetic tree based on this analysis is shown in Fig. 3.

\section{'Candidatus Helicobacter suis'-specific PCR and Southern blot hybridization}

Amplification of helicobacter DNA using the primers $V 832 f$ and $V 1261 r$ produced a 433-bp fragment from all five stomach samples. All PCR products hybridized with the V1000f probe after Southern blot hybridization. No amplification product was obtained using DNA preparations from any of the Helicobacter strains, including $H$. felis, $H$. bizzozeronii and $H$. salomonis (Table 1), nor from the negative control. PCR with the cloned reference material (2BXA) yielded $\mathrm{a} \sim 0.4 \mathrm{kbp}$ product as expected. 


\section{In situ hybridization}

In situ hybridization of ' $G$. suis'-like bacteria with the 'Candidatus Helicobacter suis'-specific probe was seen in sections from all $(5 / 5)$ stomachs. Bacteria were observed as dark-brown spiral organisms in the superficial mucus layer and the gastric crypts. In some cases, helical organisms, located deeply in the crypts, were labelled weakly or were negative. A faint background staining, seen as finely stained strings, was sometimes observed in the surrounding cells. This background staining was also observed in the $H$. pylori-infected mouse stomach that was used as a negative control. The H. pylori cells in this control did not hybridize with the 'Candidatus Helicobacter suis'-specific probe, however.

\section{DISCUSSION}

The presence of helicobacter-like organisms in the stomachs of pigs was reported for the first time in 1990 (Queiroz et al., 1990). Since then, the morphology, prevalence and potential pathogenic role of these organisms have been described in several other studies (Mendes et al., 1990, 1991; Barbosa et al., 1995; Queiroz et al., 1996). The name 'G. suis' was proposed (Mendes et al., 1990), as these bacteria were morphologically similar to 'Gastrospirillum hominis', a unculturable bacterium seen in human gastric biopsy specimens (McNulty et al., 1989).

In the present study, 16S rDNA sequences were obtained from five different porcine stomach samples containing gastrospirillum-like bacteria. A maximum divergence of less than $0.3 \%$ was found between these sequences, suggesting that they originate from strains belonging to a single species. Phylogenetic analysis placed the organism characterized by the reference sequence 2BXA within the genus Helicobacter, where it formed a distinct sub-group together with other gastrospirillum-like bacteria ( $H$. felis, $H$. bizzozeronii, $H$. salomonis and ' $H$. heilmannii' types 1 and 2) (Fig. $3)$. A very high level of $16 \mathrm{~S}$ rDNA sequence similarity $(99.5 \%)$ was found towards ' $H$. heilmannii' type 1 . This is in agreement with previously reported data on the phylogenetic position of ' $G$. suis', described in a poster presented at the 7th workshop of the European Helicobacter pylori Study Group (Mendes et al., 1994) (the 16S rDNA sequence determined in the latter study has not been deposited in an international database).

A clearly lower level of $16 \mathrm{~S}$ rRNA similarity was observed towards the other species characterized by the gastrospirillum morphology, and alignment of the V2BXA 16S rDNA sequence allowed the design of primers and a probe that were specific for the sequences derived from the porcine samples. DNA from none of the other helicobacters examined yielded a product. In situ hybridization with a specific probe associated the reference sequence to the spiral organisms seen in the gastric crypts of pigs, confirming that our $16 \mathrm{~S}$ rRNA sequences corresponded to the ' $G$. suis' cells observed in the gastric specimens. These results indicate that the porcine sequences represent a taxon that can be differentiated from all known helicobacter species. The low level of similarity towards $H$. salomonis $(96 \cdot 6 \%)$, its closest validly named neighbour, strongly suggests that this taxon is a novel helicobacter species. Conforming with the guidelines of Murray \& Schleifer (1994) and Murray \& Stackebrandt (1995), we propose to assign the porcine taxon to the category Candidatus pending further characterization of this bacterium after in vitro cultivation of strains. The availability of the nearly complete $16 \mathrm{~S}$ rDNA sequence and the specific PCR assay and probe provide the scientific community with an instrument to analyse the prevalence and role of this bacterium.

Analysis of 16S rDNA sequences of human gastrospirilla (' $G$. hominis') revealed not only that these bacteria also belong to the genus Helicobacter (and as a consequence the name ' $H$. heilmannii' has been used to denote the same organism), but that there are at least two different types, commonly referred to as types 1 and 2 (O'Rourke et al., 1992; Solnick et al., 1993). This observation was based on a $3.5 \%$ sequence difference, suggesting that the two sequences represented two different species. ' $H$. heilmannii' type 2 belongs phylogenetically to the $H$. felis- $H$. bizzozeronii- $H$. salomonis sub-cluster and its relatedness towards these three species needs further study. As ' $H$. heilmannii' type 1 shares $99 \cdot 5 \%$ of its $16 \mathrm{~S}$ rRNA sequence with ' $G$. suis' (Queiroz et al., 1996; this study), it is tempting to speculate that both taxa represent the same species and that ' $H$. heilmannii' type 1 infection is a zoonosis from pigs. However, strains of different species may share such high levels of $16 \mathrm{~S}$ rDNA sequence similarity (Stackebrandt \& Goebel, 1994), as is illustrated by the high similarity between, for instance, $H$. felis, $H$. bizzozeronii and $H$. salomonis (Jalava et al., 1997). As the relationship between ' $H$. heilmannii' type 1 and ' $G$. suis' can be determined fully only after cultivation of strains from both taxa, we propose the name 'Candidatus Helicobacter suis' for the porcine gastrospirillum.

The description is as follows: 'Candidatus Helicobacter suis' [( $\varepsilon$-Proteobacteria), genus Helicobacter; porcine isolates have been propagated in mice, but not in vitro; Gram-negative; Helical; NAS (GenBank accession no. AF 127028), oligonucleotide sequence complementary to unique region of $16 \mathrm{~S}$ rRNA gene 5'-AGCCGCGAGGCAGAGCTAATC-3'; morphology, $2.5-3.5 \times 0.6 \mu \mathrm{m}$, multiple complete spiral turns with a wavelength of $\sim 600 \mathrm{~nm}$, multiple bipolar flagella; symbiotic (Sus, stomach); strong urease activity, cross-reaction with polyclonal $H$. pylori-derived antibodies].

\section{ACKNOWLEDGEMENTS}

D.D.G. is indebted to the Flemish Institute for the Encouragement of Research in the Industry (Grant SB/ 951027). P. V. is indebted to the Scientific Research Fund- 
Flanders (Belgium) for a position as postdoctoral research fellow. We thank Dr Charlier and Dr Roels of the Centre for Research in Veterinary Medicine and Agrochemistry (CODA) for their help with the electron microscopy. We are also grateful to Mrs K. Tilmant for her help with the immunohistochemical and in situ hybridization techniques and $\mathrm{Mr} \mathrm{C}$. Puttevils and Mr J. P. Logghe for their technical assistance.

\section{REFERENCES}

Altschul, S. F., Madden, T. L., Schäffer, A. A., Zhang, J., Zhang, Z., Miller, W. \& Lipman, D. J. (1997). Gapped BLAST and PSI-BLAST: a new generation of protein database search programs. Nucleic Acids Res 25, 3389-3402.

Barbosa, A. J., Silva, J. C., Nogueira, A. M., Paulino Junior, E. \& Miranda, C. R. (1995). Higher incidence of Gastrospirillum sp. in swine with gastric ulcer of the pars oesophagea. Vet Pathol 32, 134-139.

Bizzozero, G. (1893). Ueber die schlauchförmigen Drüsen des magendarmkanals und die Beziehungen ihres Epithels zu dem Oberflächenepithel der Schleimhaut. Arch Mikrosk Anat 42, 82.

Blaser, M. J., Perez-Perez, G. I., Lindenbaum, J., Schneidman, D., Van Deventer, G., Marin-Sorensen, M. \& Weinstein, W. M. (1991). Association of infection due to Helicobacter pylori with specific upper gastrointestinal pathology. Rev Infect Dis 13 (suppl. 8), S704-S708

Boom, R., Sol, C. J. A., Salimans, M. M. M., Jansen, C. L., Wertheim-van Dillen, P. M. E. \& van der Noordaa, J. (1990). Rapid and simple method for purification of nucleic acids. $J$ Clin Microbiol 28, 495-503.

Cover, T. L. \& Blaser, M. J. (1995). Helicobacter pylori: a bacterial cause of gastritis, peptic ulcer disease, and gastric cancer. $A S M$ News 61, 21-26.

Dent, J. C., McNulty, C. A. M., Uff, J. C., Wilkinson, S. P. \& Gear, M. W. L. (1987). Spiral organisms in the gastric antrum [letter]. Lancet ii, 96.

Dewhirst, F. E., Seymour, C., Fraser, G. J., Paster, B. J. \& Fox, J. G. (1994). Phylogeny of Helicobacter isolates from bird and swine feces and description of Helicobacter pametensis sp. nov. Int $J$ Syst Bacteriol 44, 553-560.

Eaton, K. A., Radin, M. J., Kramer, L., Wack, R., Sherding, R., Krakowka, S., Fox, J. G. \& Morgan, D. R. (1993). Epizootic gastritis associated with gastric spiral bacilli in cheetahs (Acinonyx jubatus). Vet Pathol 30, 55-63.

Franklin, C. L., Beckwith, C. S., Livingston, R. S., Riley, L. K., Gibson, S. V., Besch-Williford, C. L. \& Hook, R. R., Jr (1996). Isolation of a novel Helicobacter species, Helicobacter cholecystus sp. nov., from the gallbladders of Syrian hamsters with cholangiofibrosis and centrilobular pancreatitis. $J$ Clin Microbiol 34, 2952-2958.

Hänninen, M.-L., Happonen, I., Saari, S. \& Jalava, K. (1996). Culture and characteristics of Helicobacter bizzozeronii, a new canine gastric Helicobacter sp. Int J Syst Bacteriol 46, 160-166.

Jakob, W., Stolte, M., Valentin, A. \& Schroder, H. D. (1997). Demonstration of Helicobacter pylori-like organisms in the gastric mucosa of captive exotic carnivores. J Comp Pathol 116, $21-33$

Jalava, K., Kaartinen, M., Utriainen, M., Happonen, I. \& Hänninen, M.-L. (1997). Helicobacter salomonis sp. nov., a canine gastric Helicobacter sp. related to Helicobacter felis and Helicobacter bizzozeronii. Int J Syst Bacteriol 47, 975-982.

Lapage, S. P., Sneath, P. H. A., Lessel, E. F., Skerman, V. B. D.,
Seeliger, H. P. R. \& Clark, W. A. (editors) (1992). International Code of Nomenclature of Bacteria. (1990 Revision). Washington, DC: American Society for Microbiology.

Lee, A., Hazell, S. L., O'Rourke, J. \& Kouprach, S. (1988). Isolation of a spiral-shaped bacterium from the cat stomach. Infect Immun 56, 2843-2850.

McNulty, C. A., Dent, J. C., Curry, A., Uff, J. S., Ford, G. A., Gear, M. W. \& Wilkinson, S. P. (1989). New spiral bacterium in gastric mucosa. $J$ Clin Pathol 42, 585-591.

Marshall, B. J. \& Warren, J. R. (1984). Unidentified curved bacilli in the stomach of patients with gastritis and peptic ulceration. Lancet i, 1311-1315.

Mendes, E. N., Queiroz, D. M. M., Rocha, G. A., Moura, S. B., Leite, V. H. R. \& Fonseca, M. E. F. (1990). Ultrastructure of a spiral micro-organism from pig gastric mucosa ('Gastrospirillum suis'). J Med Microbiol 33, 61-66.

Mendes, E. N., Queiroz, D. M. M., Rocha, G. A., Nogueira, A. M., Carvalho, A. C., Lage, A. P. \& Barbosa, A. J. (1991). Histopathological study of porcine gastric mucosa with and without a spiral bacterium ('Gastrospirillum suis'). J Med Microbiol 35, 345-348.

Mendes, E. N., Queiroz, D. M. M., Dewhirst, F. E., Paster, B. J., Rocha, G. A. \& Fox, J. G. (1994). Are pigs a reservoir host for human Helicobacter infection? (abstract). Am J Gastroenterol 89, 1296

Mendes, E. N., Queiroz, D. M. M., Coimbra, R. S., Moura, S. B., Barbosa, A. J. \& Rocha, G. A. (1996a). Experimental infection of Wistar rats with 'Gastrospirillum suis'. $J$ Med Microbiol 44, 105-109.

Mendes, E. N., Queiroz, D. M. M., Dewhirst, F. E., Paster, B. J., Moura, S. B. \& Fox, J. G. (1996b). Helicobacter trogontum sp. nov., isolated from the rat intestine. Int $J$ Syst Bacteriol 46, 916-921.

Moura, S. B., Queiroz, D. M., Mendes, E. N., Nogueira, A. M. \& Rocha, G. A. (1993). The inflammatory response of the gastric mucosa of mice experimentally infected with 'Gastrospirillum suis'. J Med Microbiol 39, 64-68.

Murray, R. G. E. \& Schleifer, K. H. (1994). Taxonomic notes: a proposal for recording the properties of putative taxa of procaryotes. Int J Syst Bacteriol 44, 174-176.

Murray, R. G. E. \& Stackebrandt, E. (1995). Taxonomic note: implementation of the provisional status Candidatus for incompletely described procaryotes. Int $J$ Syst Bacteriol 45 , 186-187.

On, S. L. (1996). Identification methods for campylobacters, helicobacters, and related organisms. Clin Microbiol Rev 9 , 405-422.

On, S. L. W., Bloch, B., Holmes, B., Hoste, B. \& Vandamme, P. (1995). Campylobacter hyointestinalis subsp. lawsonii subsp. nov., isolated from the porcine stomach, and an emended description of Campylobacter hyointestinalis. Int J Syst Bacteriol 45, 767-774.

O'Rourke, J., Solnick, J., Lee, A. \& Tompkins, L. (1992). Helicobacter heilmannii (previously Gastrospirillum), a new species of Helicobacter in humans and animals [abstract]. Ir J Med Sci 161 (suppl. 10), 31.

Parsonnet, J., Friedman, G. D., Vandersteen, D. P., Chang, Y., Vogelman, J. H., Orentreich, N. \& Sibley, R. K. (1991). Helicobacter pylori infection and the risk of gastric carcinoma. $N$ Engl $J$ Med 325, 1127-1131.

Paster, B. J., Lee, A., Fox, J. G., Dewhirst, F. E., Tordoff, L. A., Fraser, G. J., O'Rourke, J. L., Taylor, N. S. \& Ferrero, R. (1991). 
Phylogeny of Helicobacter felis sp. nov., Helicobacter mustelae, and related bacteria. Int $J$ Syst Bacteriol 41, 31-38.

Queiroz, D. M. M., Rocha, G. A., Mendes, E. N., Lage, A.P., Carvalho, A. C. T. \& Barbosa, A. J. A. (1990). A spiral microorganism in the stomach of pigs. Vet Microbiol 24, 199-204.

Queiroz, D. M. M., Rocha, G. A., Mendes, E. N., De Moura, S. B., De Oliveira, A. M. \& Miranda, D. (1996). Association between Helicobacter and gastric ulcer disease of the pars esophagea in swine. Gastroenterology 111, 19-27.

Rappin, J. (1881). Contribution à l'étude de bactéries de la bouche à l'état normal. $\mathrm{PhD}$ thesis, Collège de France, Nantes, France.

Seymour, C., Lewis, R. G., Kim, M., Gagnon, D. F., Fox, J. G., Dewhirst, F. E. \& Paster, B. J. (1994). Isolation of Helicobacter strains from wild bird and swine feces. Appl Environ Microbiol 60, 1025-1028.

Shen, Z., Fox, J. G., Dewhirst, F. E., Paster, B. J., Foltz, C. J., Yan, L., Shames, B. \& Perry, L. (1997). Helicobacter rodentium sp. nov., a urease-negative Helicobacter species isolated from laboratory mice. Int J Syst Bacteriol 47, 627-634.
Solnick, J. V., O'Rourke, J., Lee, A., Paster, B. J., Dewhirst, F. E. \& Tompkins, L. S. (1993). An uncultured gastric spiral organism is a newly identified Helicobacter in humans. J Infect Dis $\mathbf{1 6 8}$, 379-385.

Stackebrandt, E. \& Goebel, B. M. (1994). Taxonomic note: a place for DNA-DNA reassociation and $16 \mathrm{~S}$ rRNA sequence analysis in the present species definition in bacteriology. Int $J$ Syst Bacteriol 44, 846-849.

Trüper, H. G. \& De'Clari, L. (1997). Taxonomic note: necessary correction of specific epithets formed as substantives (nouns) 'in apposition'. Int J Syst Bacteriol 47, 908-909.

Vandamme, P., Falsen, E., Rossau, R., Hoste, B., Segers, P., Tytgat, R. \& De Ley, J. (1991). Revision of Campylobacter, Helicobacter, and Wolinella taxonomy: emendation of generic descriptions and proposal of Arcobacter gen. nov. Int J Syst Bacteriol 41, 88-103.

Weisburg, W. G., Barns, S. M., Pelletier, D. A. \& Lane, D. J. (1991). $16 \mathrm{~S}$ ribosomal DNA amplification for phylogenetic study. $J$ Bacteriol 173, 697-703. 